\title{
Cytotoxic Activity of I-(2,5-dihydroxyphenyl)-3-pyridine- 2-yl-propenone on Colon Cancer Cell WiDr
}

\author{
Nur Ismiyati ${ }^{1}$, Yuli Puspito Rini ${ }^{1}$, Andy Eko Wibowo ${ }^{1}$, Ratna Asmah Susidarti ${ }^{2}$ \\ ${ }^{1}$ Diploma Program of Pharmacy, Poltekkes Bhakti Setya, Yogyakarta, Indonesia \\ ${ }^{2}$ Faculty of Pharmacy, Universitas Gadjah Mada, Yogyakarta, Indonesia
}

\begin{abstract}
Colon cancer is one of the most common death-caused cancer. The high mortality rate indicates that chemotherapy has not overcome cancer disease. Strategies and development of colon cancer treatment should be pursued. Compound I-(2,5dihydroxyphenyl)-3-pyridine-2-yl-propenone is the 2',5'-dihydroxychalcone derivative, of which the B ring was substituted with 2-pyridine ring. Chalcone and its derivatives have been reported to have several biological activities, such as cytotoxic, anti-inflammatory, antiHIV, and as a tyrosine kinase inhibitor. The objectives of this research was to determine the cytotoxic activity on WiDr colon cancer cells of I-(2,5-dihydroxyphenyl)-3-pyridine-2-ylpropenone. Cytotoxic activity was measured using MTT assay. Compound I-(2,5dihydroxyphenyl)-3-pyridine-2-yl-propenone inhibited WiDr cell growth with the $\mathrm{IC}_{50}$ of 16 $\mu \mathrm{M}$. Morphology of WiDr cell showed that compound I-(2,5-dihydroxyphenyl)-3-pyridine-2yl-propenone inhibited cell growth in dose dependent.
\end{abstract}

Keywords: compound I-(2,5-dihydroxyphenyl)-3-pyridine-2-yl-propenone, WiDr colon cancer cell line, cytotoxic activity.

\section{INTRODUCTION}

Cancer is the disease causing high number of mortality. In Indonesia, colon cancer become the most dangerous gastrointestinal disease after the hepotocelular cancer (Pusponegoro, 2004). Colon cancer could develop by the overexpression of cyclooxigenase 2 (COX-2) (Turíni and Dubois, 2002). In the therapy of colon cancer, 5fluorouracil (5-FU) is used for the main therapy, but cannot give the satisfying result and just give effectivity in the therapy for approximately $20 \%$ of colon cancer patient (Arkenau, et al., 2005; Meyerhardt and Mayer, 2005). Therefore, the research for the invention and the development for new compound for colon canacer treatment is need to be done.

One of the potential compound to develop as the cancer chemoprevention agent is the analog of calcon compound. Calcon is the compound having basic structure $\mathrm{C}_{6} \mathrm{C}_{3} \mathrm{C}_{6}$, where two aromatic rings (ring $\mathrm{A}$ and ring $\mathrm{B}$ ) are connected with three atomic carbon. Calcon structures are generally found in flavonoid compounds. These compounds are found in fruits, vegetables, nuts, and tea (Patil, et al., 2009). Calcon and its derivates are reported to have biological activities such as cytotoxicity, antimalaria, antileismania, antiinflamation, antiHIV, antifungi, and tyrosine kinase inhibitor (Saxena, et al., 2007).

The modification of lacton compound with the change of fenyl ring on $B$ position of 4-cloro-2',4'-dihidroxycalcon and 2',5'dihydroxycalcon with 2-piridyl and their activity in anticancer have not been reported. Some of the modified compounds are 1-(2,4dihydroxyfenil)-3-piridin-2-il-propenon; 1-(2,5dihydroxyfenil)-(3-piridin-2-il)-propenon; 4cloro-2',4'-dihydroxycalcon; and 2',5'dihydroxycalcon.

*Corresponding author e-mail: nur_is@yahoo.com 
The aim of this research is to test the cytotoxic potency of 1-(2,5-dihydroxyfenil)-(3piridin-2-il)-propenon in colon cancer cell WiDr. The synthesis of 1-(2,5-dihydroxyfenil)(3-piridin-2-il)-propenon has been succesfully done and showed the antiinflamation activity (Wibowo, 2013).

The result of this study hopefully could be the basic theory in the development of 1(2,5-dihydroxyfenil)-(3-piridin-2-il)-propenon as the alternative of chemoprevention agent in colon cancer cell.Brazilein inhibits survivin protein and induces apoptosis in HepG2 hepatocellular carcinoma cells (Zhong, et al., 2009). This study was conducted to evaluate the cytotoxic effect of brazilein, both alone and in combination with doxorubicin on MCF-7/DOX cells by using MTT assay.

\section{MATERIALS AND METHODS}

\section{Cell Culture}

Colon cancer cell WiDr is the collection of CCRC Faculty of Pharmacy UGM. WiDr cells were cultured in the RPMI (Gibco). The culture media contained 10\% FBS (Ginco) and 1\% Penisilin Streptomicyn (Gibco). Cells were cultured in the temperature of $37^{\circ} \mathrm{C}$ and $5 \%$ $\mathrm{CO}_{2}$. Cells are harvested with tripsin $0.25 \%$ (Gibco).

\section{Cytotoxic assay}

Exponentially The cytotoxic assay were done by MTT Assay. WiDr cells were distributed in 96-well plate as many as $10 \times 10^{3}$ cells/ well. Cells were incubated for 24 hours in $\mathrm{CO}_{2}$ incubator then were added with $100 \mu \mathrm{L}$ of culture media containing sample in some concentration for 3 replication each concentration and then incubated again for 24 hours. As the control are the DMSO solution, WiDr cell control, and culture media control (RPMI). In the end of the incubation time, the culture media were removed and cells were washed with PBS. Then in each well were added by $100 \mu \mathrm{L}$ MTT reagen and incubated for three hours in the temperature of $37^{\circ} \mathrm{C}$ and $5 \% \mathrm{CO}_{2}$. After three hours, the solution of $10 \%$ SDS in $0.1 \mathrm{~N} \mathrm{HCl}$ were added as stopper reagen. Cells were incubated for a night in the room temperature and protected from the light, and the plate were shaked horizontally (with shaker) for 10 minutes, then were read with ELISA reader (BioRad) in $\lambda 595 \mathrm{~nm}$.

\section{RESULT AND DISCUSSION}

The cytotoxic assay give the potency evaluation of 1-(2,5-dihydroxyfenil)-(3-piridin2-il)-propenon in the inhibition of colon cancer cell WiDr growth. The paramereter used in this research is the inhibition concentration $50 \%$ $\left(\mathrm{IC}_{50}\right)$. The lower the $\mathrm{IC}_{50}$ value, the tested compound is more potent in the inhibition of cancer cell growth. The result of cytotoxic assay showed that 1-(2,5-dihydroxyfenil)-(3piridin-2-il)-propenon in the concentration of 1$100 \mu \mathrm{M}$ has the cytotoxic activity towards WiDr cell in dose dependent manner. The higher the concentration of 1-(2,5dihydroxyfenil)-(3-piridin-2-il)-propenon given, the lower the percent of cell viability (Fig. 1).

Based on the calculation by the linier regretion $\log$ concentration versus \% cell viability showed that -(2,5-dihydroxyfenil)-(3piridin-2-il)-propenon gives $\mathrm{IC}_{50}$ values $16 \mu \mathrm{M}$ on WiDr cell. This result showed that the tested compound has the better sensitivity and selectivity towards Colon cancer cell WiDr, than towards 5-fluorouracil (5-FU) with IC50 $496 \mu \mathrm{M}$ (Ikawati, 2008). The observation of cell morfology after the treatment with tested compound showed the number of death cells were increasing as the concentration of 1-(2,5dihidroksifenil)-(3-piridin-2-il)-propenon were increased. 


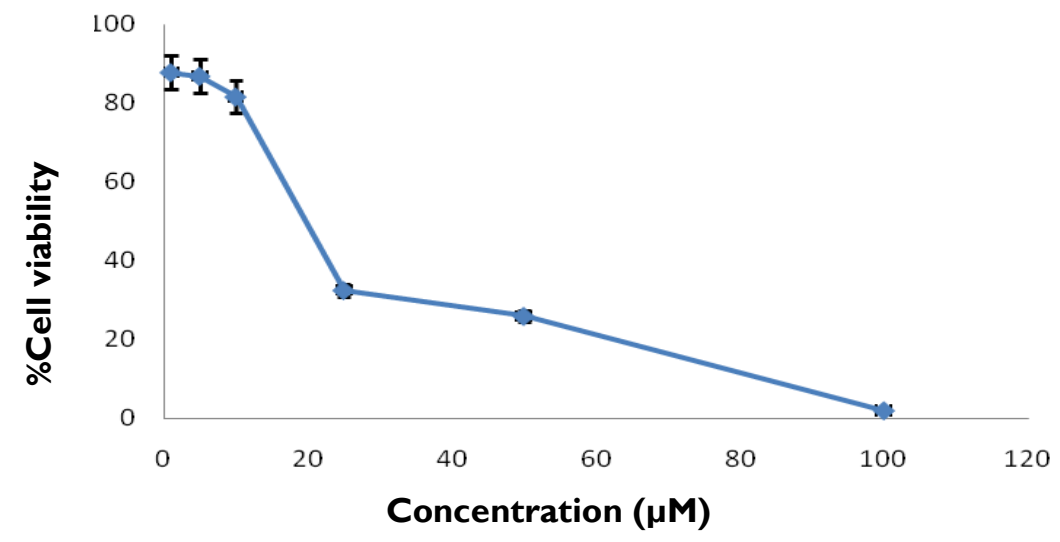

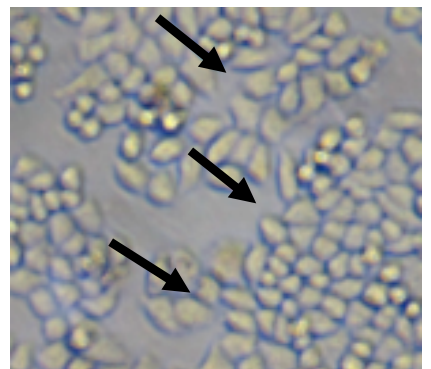

(B)

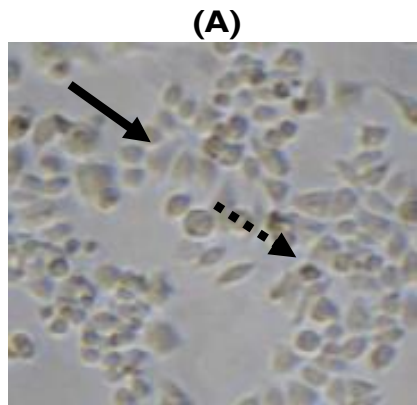

(C)

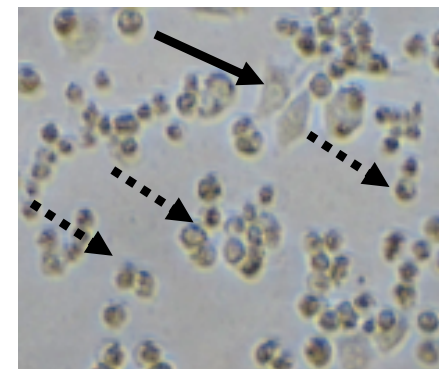

(D)

Figure I. The cytotoxic effect of I-(2,5-dihydroxyphenyl)-3-pyridine-2-yl-propenone on WiDr cells. The cells were treated with I-(2,5-dihydroxyphenyl)-3-pyridine-2-yl-propenone in the concentration of $\mathrm{I}-100 \mu \mathrm{M}$ and then incubated for $24 \mathrm{~h}$. After 24 hours, cells were added by MTT reagent to calculate the absorbance which represent viable cells. (A) Diagram of WiDr cells viability after 24 hours I-(2,5dihydroxyphenyl)-3-pyridine-2-yl-propenone treatment. WiDr cells morphology of (B) cell control; (C) after 24 hours $10 \mu \mathrm{M}$; (D) $50 \mu \mathrm{M}$ I-(2,5-dihydroxyphenyl)-3-pyridine-2-yl-propenone treatment. Observation was done by using converted microscope with $400 \times$ magnification. Cell viability profile was shown from average \pm standard of error (SE) of 3 experiments. The normal cells are showed by the bold arrow ( $\longrightarrow$ ) and the changed morphology cells are showed by the thin Arrow ( $\longrightarrow$ ).

\section{CONCLUSION}

Compound 1-(2,5-dihydroxyphenyl)-3pyridine-2-yl-propenone has the cytotoxic activity in the inhibition of colon cancer cell WiDr with $\mathrm{IC}_{50}$ value $16 \mu \mathrm{M}$.

\section{ACKNOWLEDGEMENT}

We would like to say thank you for DIKTI through Hibah Penelitian Dosen Pemula for the funding given in this research, also for Poltekkes Bhakti Setya Indonesia, and fAculty of Pharmacy UGM, and Cancer Chemoprevention Research Center (CCRC) for the supports and facilities given.

\section{REFERENCES}

Arkenau, H.T., Rettig, K. and Porschen, R., 2005, Adjuvant Chemotherapy in Curative Resected Colon Carcinoma: 5-Fluorouracil/Leucovorin versus Highdose 5-Fluorouracil 24-h Infusion/Leucovorin versus High-dose 5-Fluorouracil 24-h Infusion, Int. J. Colorectal Dis., 20(3), 258-26I.

Ikawati, M., 2008, Modulasi Daur Sel dan Pemacuan Apoptosis pada Sel Kanker Kolon Widr oleh Perlakuan Tunggal Pentagamavunon-0 dan Kombinasinya dengan 5-Fluorouracil, Thesis, Universitas Gadjah Mada, Yogyakarta.

Meyerhardt, J.A. and Mayer, R.J., 2005, Systemic Therapy for Colorectal 
Cancer, N. Engl. J. Med., 352(5), 476487.

Patil, B.C., Mahajan, S.K. and Katti, A.S., 2009, Chalcone: A Versatile Molecule, J. Pharm. Sci. Res., I, II-22.

Pusponegoro, A.D., 2004, Epidemiologi Keganasan Saluran Cerna, Proceeding Temu Ilmiah Multimodalitas Terapi Pada Keganasan Saluran Cerna, Jakarta.
Saxena, H.O., Faridi, U., Kumar, J.K., Luqman, S., Darokar, M.P., Shanker, K., et al., 2007, Synthesis of Chalcone Derivatives on Steroidal Framework and Their Anticancer Activities, Steroids, 72(I3), 892-900.

Turini, M.E. and DuBois, R.N., 2002, Cyclooxygenase2: A Therapeutic Target, Annu. Rev. Med., 53(I), 35-57. 